\title{
Asian and African Business Students: A Comparative Analysis of their Motivation, Family Support and Culture on Business Orientation
}

\begin{abstract}
Submitted 28/11/19, $1^{\text {st }}$ revision 17/12/19, $2^{\text {nd }}$ revision 20/01/20 accepted 03/02/20
\section{Abstract:}

\author{
Genoveva Genoveva $^{1}$, Filbertha Nathania Kartawaria ${ }^{2}$
}

Purpose: The aim of this research is to analyze Asian and African business students' motivation, family support and culture on business orientation.

Design/Methodology/Approach: The research method used is both qualitative and quantitative, where quantitative data is obtained through an online questionnaire of 335 respondents, then the data is supplemented by in-depth interviews with respondents to obtain more complete data. Quantitative data is processed using SPSS software statistical program.

Findings: The results showed that descriptively there were differences of Asian and African business students. Based on t-test and F-test, there are positive and significant motivation, family support and culture aspects on business orientation in both groups of students. The results are also in-line with some of similar previous researches where the factor that most influence business orientation is culture.

Practical implications: For the university and family business, this study can be useful as one of the materials discussion in the family business class and also design the curriculum. The results of this study shown that, culture have the big contibution on business students orientation. Therefore the univesity and family business can include culture as one of the topic of entrepreneurship curriculum.

Originality/Value: This research specifies and focuses on comparative analysis of Asian and African business students, the result can be use for design the business students curriculum, therefore the business motivation indexes of Asian and African can be increase through entrepreneurship education in business schools.
\end{abstract}

Keywords: Entrepreneurship, entrepreneurship curriculum, business students.

JEL Codes: L26.

Paper Type: Research study.

Acknowledgments:

This research and resulting contribution are with the patronage of President University, Indonesia, School of Business research project based on a lecturer's obligation of 2019.

\footnotetext{
${ }^{1}$ AssociateProffesor, President University, Indonesia, School of Business, genoveva@president.ac.id

${ }^{2}$ Katholieke Universiteit Leuven, Belgium, Business Administration, filbertha@gmail.com
} 


\section{Introduction}

Based on the trend of the world's population growth until 2050, Asia will continue to occupy the number one position (5.231.5 millon people), followed by Africa (1.753.3 million people) (Carbonnier, Chakraborty and Mulle, 2010). On the other hand the results of research from the Global Entrepreneurship Monitor (GEM, 2018) states that motivation indexes from Asia and Africa are the two continents that have the lowest indexes, namely Africa 1.5 and Asia 3.2. This contradictory condition can cause serious problems with education, health and daily needs. Macham (2015) said that human capital is very important for a country's economic growth. The same thing was also stated by a number of researchers such as Figueroa-Armijos and Jhonson (2016), Toma, Grigore and Marinescu (2014) and Naude (2013) who concluded that entrepreneurship is one of the effective ways to increase the economic growth of a country. In addition, entrepreneurship has long been identified as a critical driving force of economic growth and prosperity (Praag and Praag, 2008).

Naude (2013) also found one of the ways to grow the number of entrepreneurs is through tertiary education. Since 1970 there has been an increase in the number of universities and colleges opening entrepreneurial-related programs (Kuratko, Hornsby and Covin, 2013). The entrepreneurship program is offered in a variety of options, such as major and/or minor courses, certificates and Master's programs. Teachers also support research in the field of entrepreneurship (Morris, Kuratko and Cornwall, 2013). By increasing the programs that offer entrepreneurship in business schools, this can foster leadership, innovation and entrepreneurship that are needed by entrepreneurs (Kuratko, 2005).

In addition, to increase entrepreneurship education is the driver of growth in entrepreneurs (Naude, 2013). Other factors also influence one's desire to entrepreneurship are motivational factors as stated in other researches (Mclelland, 1961; Bandura, 1997; Borgia, 2005; Jordaan, 2014; Genoveva, 2019). Robbins and Judge (2013) defines motivation as a process that explains the intensity, direction and persistence of effort to achieve a goal.

If someone has motivation then he has a clear goal, this is the trait that must be possessed by an entrepreneur. The next factor is family support (Joseph, 2012; Neneh, 2017; Genoveva, 2019) and tradition (Adendorff, 2011; He, 2011; Vainionkulma, 2016). Neneh's results (Neneh, 2017) show that family support is very strong especially for those who carry out their functions as the responsible person in the family. Joseph (2012) and Senjaya and Genoveva (2019) said something similar to Neneh (2017) where the family strongly supports family members who choose business in their studies. While traditionally, those whose families do business tend to have a desire to do business (He, 2011). 


\section{Literature Review and Legislative Background}

In developing countries, entrepreneurship is considered vital for enhancing employment opportunities. Asia and Africa as the two continents with the majority of countries including developing countries are very interested in increasing the number of entrepreneurs. Entrepreneurship researchers have identified various determinants of individual entrepreneurial intentions. Entrepreneurship education has been recognized as one of the important determinant of entrepreneurial intentions. Various studies like Galloway and Brown (2002), Kuratko (2005), Potter et al. (2017), Fayolle and Gailly (2008), Patricia and Silangen (2016), Ndofirepi and Rambe (2017), Senjaya and Genoveva (2019) and Genoveva (2019) empirically demonstrated the entrepreneurial education as an important determinant of business orientation. Several previous studies by the authors concluded that there is influence of some factors on business orientation of business students, such as cultural factors, family support, self-efficacy, motivation, and e-commerce (Genoveva, 2019; Senjaya and Genoveva, 2019).

\section{a. Demographic:}

The demographic factor divides customers into segments based on demographic characteristics such as age, gender, family size, family life cycle, income, occupation, education, religion, race, generation, social class and nationality (Armstrong and Kotler, 2005). From the overall demographic aspect, this study only uses the age, gender and family business ownership by origin. A person's age is considered a major demographic characteristic in understanding his entrepreneurial behavior and intentions. In many developing countries entrepreneurs aged 25-34 years are in the early stages and the 35-44 age groups is an early-stage entrepreneur in the developed world. Among the level of activity achievement of entrepreneurial success is at the age of 25-34 years and decreased at the age of 35-44 years (Ozdemir and Karadeniz, 2009). While, gender has an influence on entrepreneurial desires, entrepreneurial women have better performance than male (Djajagunawan and Genoveva, 2018). Among some researchers who explain groups that have family businesses have higher entrepreneurial intention than those who do not have a family business (Genoveva, 2019; Chrisman, Chua and Steier, 2003; Nandamuri and Gowtami, 2013).

\section{b. Motivation:}

The traditional motivation of the entrepreneur is to get the money, in this era money is not a reason why entrepreneurs count other factors such as to provide social benefit to others, practise the knowledge, maximaze their creativity and desire of achievement (Nugraha and Indra, 2016). McCelland in Genoveva (2019) state that motivation in entrepreneurship is needed for achievement, the entrepreneurial behavior that is manifested in attitudes and motivation on a successful career and achievement is reflected in the following actions: adapting for achieve success, action oriented, high responsibility, good supervising and motivation. To be successful in entrepreneurship, entrepreneurs must have motivation that support the 
success of the business. The motivation can be seen from the traits such as risktaking, neeed for achievement, goal setting, self efficacy, locus of control and tolerance for ambiquity (Shane, Locke and Collins, 2003).

The motivation in this research is the drive to be oriented towards business through education in the business field, including participating in supporting activities such as attending seminars, workshops, mentorship with business owners and finding information related to business plans. From all the definitions above, we can concluded that there is influence motivation on business orientation.

\section{c. Family Support:}

Shen, Osorio and Settles (2017) state that family support is how family involves in business, included support on business advice, financial, material and emotional access. Several studies have shown that there is an influence of family support on business orientation, as in the results of the study of Schwartz (2009) who said that support is not only from family but also from friends. In line with Schwarz (2009) and Shen, Osorio and Settles (2017) Bae and Qian (2014) stated that is a relationship between family support and business. Social network is very important to start a business, they can be friends, relatives and family members. Therefore family members play crucial role in influencing the students on business intention.

Aldrich and Cliff (2003), Sequiera and Carr (2007), Shen, Osorio and Settles (2017) claimed that the business students who come from families who have businesses pay more attention to business, compared to those whose families do not do business (Genoveva, 2019). Families that have strong ties with their children will learn business from childhood and get mentoring directly from their parents and the other senior family members. The other supporting fector from family with business is the business education, mostly the business students also choose business as their studies. The family hope, after finished their studies, is that they will contribute in family business (Genoveva, 2019). The supporting factor from the family is not only the intellectual support (education) but also the emotional support (Procidano and Keller, 1983).

The nuclear family is the family where the family couple and the children lived together as a common phenomenon of African countries. While lived together, they can support each others in their family business (Ugwuja, 2010). There is little difference between Africa and Asia business students where economically capable families generally do not live with their core families, but they still support each other in the family business (Korobova, 2012).

\section{d. Culture:}

Understanding of culture has changed the definition from the 19th century, where Taylor and Kroeber (Hamid, 2013) define culture as the behavior of a group of people which includes knowledge, beliefs, art, rules, laws and habits. The similar definition concluded by Kotler and Amstrong (2017), tradition and culture of family 
as the pattern of values, norms, beliefs, attitudes and assumptions that may not have been articulated but shape the ways in which people in organizations behave and things get done. Kluckhohn (1951) provides a new dimension that is set about the habits of society which is passed on to others including how to feel, think, understand the patterns created in special symbols. The definition of culture in the family is beneficial when family habits among others solve the problem in a family way. In addition, strong kinship replaces work contracts, work agreements and various business process activities which is often found in non-family business. The family culture is part of the distinctive factor for competitiveness and maintain quality. The dimension of culture values in family business consist of the following (Vallejo, 2009):

1) Commitment and loyalty transmitted by families strengthen ties between members and contributes to family survival.

2) Harmony greates better human relationship within the family.

3) Long-term orientation demonstrates the existence of a lower level of indedtedness.

4) Culture is the most influential fector on the development of entrepreneurial competencies (Sajilan and Tehseen, 2016).

\section{e. Research Gap:}

Based on several researchers there are several factors that might influence business orientation. According to researches done by Chrisman, Chua and Steier (2003), Nandamuri and Gowtami (2013), Ozdemir and Karadeniz (2009), Djajagunawan and Genoveva (2018) and Genoveva (2019), there were several demographics (age, gender, family business ownership) that influence business students. In addition, Shane, Locke and Collins (2003) and Genoveva (2019) explain that motivation influences business orientation. Several studies have shown that there is an influence of family support on business orientation, as in the results of the study of Schwartz (2009) who said that support is not only from family but also from friends. This research fills in the gap from those researchers that were mentioned above, by focusing on motivation, family support and culture on business orientation as well as focuses on origin (Asian and African) business students.

Therefore, this research specifies and focuses on Asian and African business students, the result of questionnaire will be supplemented with in-depth interviews to get more detailed data on motivation, family support and culture on business orientation.

\section{Data and Research Methods}

The research method used in this research is both of qualitative and quantitative nature, where quantitative data is obtained through an online questionnaire of 355 respondents, then the data is supplemented by in- depth interviews with respondents to obtain more complete data. Quantitative data is processed using SPSS to test 
differences in motivation, family support and culture towards business orientation. This research uses Likert Scale as an indicator to measure the respondents' degree of agreement towards the statements of the questionnaire. The Likert Scale used was in a five-point scale (Sekaran and Bougie, 2017). Nemoto and Beglar (2014) stated that by using Likert Scale, it will be advantageous for the researcher as (a) it could gather large number of respondents quickly, (b) the validity of the interpretations from the available data can be done by any means, (c) it could provide highly reliable respondents, (d) the answer could be contrasted, compared, and combined with other qualitative data gathering method. The hypotheses of this research are :

H1: There is differences among Asia and Africa respondents by motivation, family support, culture and business orientation (by descriptive analysis).

H2: Family support is the biggest influence on business orientation of Asian and African business students.

H3: There is significant influence of motivation on business orientation of Asia and Africa business students.

H4: There is significant influence of family support on business orientation of Asia and Africa business students.

H5: There is significant influence of culture on business orientation of Asia and Africa business students.

H6: There is simultaneously significant influence of motivation, family support and culture on business orientation of Asia and Africa business students.

H7: There is strong correlation of independent variables (motivation, family support and culture) on (dependent) business orientation of Asia and Africa business students.

H8: There is big contribution of independent variables (motivation, family support and culture) on (dependent) business orientation of Asia and Africa business students.

\section{Research Results and Discussion}

The results of the validity test by using SPSS version 22.0 to determine all of 40 questions become valid by comparing the minimum requirements from $\mathrm{R}$ table of $>$ $0.361(\mathrm{a}=5 \%)$ (Sekaran and Bougie, 2017). The reliability test was done to all of 40 questions with result of high reliability, the score range is between $0.70-0.90$ (Maholtra, 2014).

Table 1 shows that although the Asian (214 respondents) and African (111 respondents) groups showed different numbers of respondents, there were no significant differences because the value of P-Value $0.001<0.05$ which means data sets are accepted, so this set can be used for further analysis. 
Table 1. Differences Test

\section{Test Statistics ${ }^{\mathbf{a}}$}

\begin{tabular}{|l|l|}
\hline & Origin \\
\hline Mann-Whitney U & 3386.500 \\
Wilcoxon W & 6389.500 \\
$\mathrm{Z}$ & -3.466 \\
Asymp. Sig. (2- & 001 \\
tailed) & \\
\hline
\end{tabular}

Note: a. Grouping Variable: Origin

Source: (Questionnaires, 2019).

In Table 2 it can be seen that the number of respondents from Asia was 211 respondents, while the Africa respondents were 124. Based on gender, both from Asia and Africa show the number of male were dominant, i.e 59.72\% for Asia and $55.65 \%$ for Africa. While based on age, respondents aged 17-21 dominate Asian and Afica respondents, namely $75 \%$ for Asia and $65 \%$ for Africa. Respondents aged > 21-25 came in the second place in both groups (Asia and Africa), as did the age group > 25 years old, Asia and Africa showed the lowest number of respondents. Both groups of respondents indicated that they had a family business background, with $75.36 \%$ from Asia and $65.32 \%$ from Africa. From the three aspects of demographics studied, namely gender, age and family business ownership, the percentage shows the same order with a percentage that is not significant different.

Table 2. Respondent Profile

\begin{tabular}{|l|l|l|l|l|}
\hline \multirow{2}{*}{ Demographic } & \multicolumn{2}{c|}{ Asia } & \multicolumn{2}{c|}{ Africa } \\
\cline { 2 - 5 } & Frequency & Percent & Frequency & Percent \\
\hline Gender : & & & & \\
Male & 126 & $59.72 \%$ & 69 & $55.65 \%$ \\
Female & 85 & $40.28 \%$ & 55 & $44.35 \%$ \\
\hline Age : & & & & \\
$17-21$ & 159 & $75.36 \%$ & 71 & $57.26 \%$ \\
$>21-25$ & 45 & $21.32 \%$ & 39 & $31.45 \%$ \\
$>25$ & 7 & $3.32 \%$ & 14 & $11.29 \%$ \\
\hline Family Business Ownership : & & & & \\
Yes & 159 & $75.36 \%$ & 81 & $65.32 \%$ \\
No & 52 & $24.64 \%$ & 43 & $34.68 \%$ \\
\hline
\end{tabular}

Source: (Questionnaires, 2019).

\subsection{Descriptive Analysis}

Table 3 shows the average scores of the Likert scale (1.00-5.00) by descriptive analysis, where Asian respondents have the highest mean for all of variables than African respondents. While Asian respondents showed the highest mean was culture (4.12), followed by family support (3.91), then business orientation (3.68) and lastly motivation (3.67). African respondents showed difference order as Asian, the highest 
was family support (3.72), in the second position was culture (3.69), the next motivation (3.45) and finally business orientation (3.23).

To sum up, there was differences among Asia and Africa respondents by motivation, family support, culture and business orientation, therefore $\mathrm{H}_{1}$ was accepted. The results are consistent with interviews with Asian and African respondents, Asian respondents showed more enthusiasm when interviewed about their study in business. Culturally today, Asian societies such as Indonesia, India, China and Vietnam provide equal opportunities for male and female to continue their studies. African respondents were represented by business students from South Africa, Zimbabwe and Algeria, also have the same opinion. Families which have business are also very supportive to their children to continue business by taking study in business majors or fields that related to business. While relating to motivation, the respondents both of Asia and Africa have the plan to continue the family business, some respondents want to start up their own business with better and more modern governance. Asian and African respondents have the same opinion, namely the family business run by their parents has not been run professionally and modernly. They have the desire to develop a family business to better utilize information technology such as doing business online besides offline (Interview, 2019). African families are very supportive of their families who want to start up or continue their family business because the number of entrepreneurs in Africa is still very lacking so that economic growth is also slow (Adendorff, 2011).

Table 3. Descriptive Analysis

\begin{tabular}{|l|l|l|l|l|}
\hline \multirow{2}{*}{ Variable } & \multicolumn{2}{|c|}{ Asia } & \multicolumn{2}{c|}{ Africa } \\
\cline { 2 - 5 } & Mean & SD & Mean & SD \\
\hline Motivation & 3.67 & 7.47 & 3.45 & 6.88 \\
\hline Family Support & 3.91 & 5.94 & 3.72 & 4.24 \\
\hline Culture & 4.12 & 6.75 & 3.69 & 7.32 \\
\hline Business Orientation & 3.68 & 7.69 & 3.23 & 7.86 \\
\hline
\end{tabular}

Source: (Questionnaires, 2019).

\subsection{Multiple Regression and T-test}

Multiple regression is an extension of simple linear regression. It is used when we want to predict the value of a variable based on the value of two or more other variables. The variable we want to predict is called the dependent variable (or sometimes, the outcome, target or criterion variable). According to Table 4 the multiple regression analysis is interpreted in the standardized equation for Asian respondents as below:

$\mathrm{Y}=4.071+0.201 \mathrm{MV}+0.195 \mathrm{FS}+0.495 \mathrm{CL}$

Where:

$\mathrm{Y}=$ Busines Orientation, $\mathrm{MV}=$ Motivation, $\mathrm{FS}=$ Family Suport, $\mathrm{CL}=$ Culture . 
Table 4 showed that all the independent variable (motivation, family support and culture) have a regression coefficient significance test lower than $\alpha(0.05)$. This indicates that all the coefficients are statistically significant therefore the independent variables have significant influence on busines orientation. This means that every $1 \%$ increase in motivation can increase the busines orientation by $20.1 \%$. As regard as family support, every $1 \%$ increase can increase the business orientation by $19.5 \%$. The biggest influence is culture, where for every $1 \%$ increase can increase the business orientation by $49.5 \%$.

The multiple regression equation for African respondents is different, the equation as follows:

$\mathrm{Y}=1.687+0.235 \mathrm{MV}+0.203 \mathrm{FS}+0.628 \mathrm{CL}$

Where:

$\mathrm{Y}=$ Busines Orientation, $\mathrm{MV}=$ Motivation, $\mathrm{FS}=$ Family Suport, $\mathrm{CL}=$ Culture.

This indicates that all the independent variables have significant influence on busines orientation. This means that every $1 \%$ increase in motivation can increase the busines orientation by $23.5 \%$. As well as family support, every $1 \%$ increase can increase the business orientation by $20.3 \%$. The biggest influence is culture, where each $1 \%$ increase can increase the business orientation by $6.28 \%$. On average all variables of African respondents' have a higher contribution than Asian respondents. The conclusion is that $\mathrm{H} 2$ is rejected, because the one who gives the biggest influence is culture, not family business of both origin.

T-test is a test that compares two groups on the mean value of a continuous (i.e., interval or ratio), normally distributed variable. The model assumes that a difference in the mean score of the dependent variable is found because of the influence of the independent variable that distinguishes the two groups. T-test in this study is to compare one by one the independent variables, namely motivation, family support and culture to business orientation (dependent variable). If the significant number < 0.05 , then the independent variables significantly influence the dependent variable (business orientation) (Table 4).

Table 4. T-test Result

Coefficients $^{\mathrm{a}}$

\begin{tabular}{|l|c|c|c|c|}
\hline \multirow{2}{*}{ Model } & \multicolumn{2}{|c|}{ Asia } & \multicolumn{2}{c|}{ Africa } \\
\cline { 2 - 5 } & B & Sig. & B & Sig. \\
\hline (Constant) & 4.071 & .234 & 1.687 & .679 \\
\hline Motivation & .201 & .042 & .235 & .029 \\
\hline Fam.Support & .195 & .033 & .203 & .037 \\
\hline Culture & .495 & .000 & .628 & .000 \\
\hline
\end{tabular}

Source: (Questionnaires, 2019). 
Asian respondents showed that motivation has a significant and positive influence on business orientation, because the significance level is $0.042<0.05$. African respondents also showed the same thing, where motivation had a significant effect on business orientation because motivation had a score of $0.029<0.05$. However, the contribution of motivation to business orientation was not big, namely $20.1 \%$ for Asian respondents and $23.5 \%$ for Africa. The results of this study are in line with other previous results (Nugraha and Indra, 2016; Senjaya and Genoveva, 2019; Genoveva, 2019). Therefore, $\mathrm{H}_{3}$ is accepted.

In addition, by deeply interview with both of the respondents' groups the result is that all of them have motivation on business orientation, however the repondents will manage the business using their own way and do not continue their parents or family business in most of the times. The respondents will be using technology, using more strategies, develop the products/services and try to get in bigger markets. According to Asian respondents, their parents are very old in style managing their business, the customer queing room is without air conditioner, the products put in the warehouse do not neatly arranged, they don't have customers' data and the payment system is cash only. African respondents also share the same things, their family business don't have any vision, trading anything in the shop (offline), although it has been proposed to sell online too (Interview, 2019).

Likewise, the results of the t-test family support on business orientation, showed significant results because it obtained a score of $0.033<0.05$ for Asian respondents. Afrika respondents do not show high influence family support on business orientation because the score is $0.203<0.05$. The result showed that $\mathrm{H}_{4}$ is accepted. The contribution of family support on business orientation from Asian respondents is $19.5 \%$, not much different compare to African respondents. This research is in-line with some previous researches (Aldrich and Cliff, 2003; Sequiera and Carr, 2007; Bae and Qian, 2014; Shen, Osorio and Settles, 2017). Sequiera and Carr (2007) say that support, not only from family, can be also from friends and relatives. The result of interview with Asian and African respondents concluded that their families fully support to study business, included the budget, facilities and the opportunities for studying abroad. Their parents hope that, after study, they will contribute to business (Interview, 2019).

The same thing was also obtained in the culture test results on business orientation, the score obtained was $0.00<0.05$, meaning that culture had a significant influence on business orientation, both on Asian and European respondents. The conclusion showed that $\mathrm{H}_{5}$ was accepted. Culture is the variable that gives the biggest contribution to business orientation, both in Asian (49.5\%) and African (62.8\%) respondents. This result is supported by previous research (Sajilan and Tehseen, 2016) which states that culture influences business orientation. Asian and African respondents said the same thing, they have a culture of mutual assistance, support and involvement in business, if their families do business. Family business is usually a source of family income. Asian and African respondents also said the same thing 
about when they were involved in helping family businesses, generally when they were at senior high school and some of the respondent when they were at the university. When compared to motivation, family support and culture are the more influential. Asian and African respondents say the same thing, while the most influential is culture, which is in accordance with the results of the t-test (Interview, 2019).

\subsection{F-Test}

F-test results show that simultaneously, predictors (independent) variables significantly influence the business orientation, both for Asian respondents $(0.00<$ $0.05)$ and African $(0.00<0.05)$. For the respondents from Asia the F value, from the corresponding F-table is 3.89 (at 5\% level) < F-test which obtained a number of 46.639, so the hypothesis was accepted. Likewise for African respondents the F valus from the F-table is 3.92 (at 5\% level) < F-test value of 59.617, meaning that the hypothesis was accepted. Based on the conclusions of the results of interviews with the two groups of respondents, respondents agreed that the three variables namely motivation, family support and culture together affect the business orientation (Interview, 2019). The result concluded that H6 was accepted (Table 5).

Table 5. F-Test (ANOVA)

\begin{tabular}{|l|l|l|l|l|}
\hline \hline \multirow{2}{*}{ Model } & \multicolumn{2}{|c|}{ Asia } & \multicolumn{2}{c|}{ Africa } \\
\cline { 2 - 5 } & F & Sig. & F & Sig. \\
\hline Regression & 46.639 & $.000^{\mathrm{b}}$ & 59.617 & $.000^{\mathrm{b}}$ \\
\hline
\end{tabular}

Note: a. Dependent Variable: Bus. Orientation b. Predictors: (Constant), Culture, Motivation, Fam.Support

Source: (Questionnaires, 2019).

\subsection{Coefficient of Correlation (R) and Coefficient of Determination (R2)}

Table 6 below shows that the $\mathrm{R}$ value is 0.734 , it is greater than 0.500 for Asian respondents, while $\mathrm{R}$ value for African respondents is 0.843 , also greater than 0.500 , which means that the correlation between the independent variables is strong for both of origin. Therefore $\mathrm{H}_{7}$ was accepted.

Table 6. Coefficient of Correlation and Determination

\begin{tabular}{|l|l|c|l|cc|}
\hline \multirow{3}{*}{ Model } & \multicolumn{3}{|c|}{ Asia } & \multicolumn{2}{c|}{ Africa } \\
\cline { 2 - 6 } & $\mathrm{R}$ & $\begin{array}{r}\text { Adjusted } \\
\text { Square }\end{array}$ & $\mathrm{R}$ & $\begin{array}{r}\text { Adjusted } \\
\text { Square }\end{array}$ & $\mathrm{R}$ \\
\hline 1 & $.734^{\mathrm{a}}$ & .527 & $.843^{\mathrm{a}}$ & .698 \\
\hline
\end{tabular}

Source: (Questionnaires, 2019).

Furthermore, Asian respondents have adjusted R square which is 0.527 . This number indicates that $52.7 \%$ of changes in the dependent variable (busines orientation) is contributed by the independent variables (motivation, family suport and Culture) in 
this research. Meanwhile the other $47.3 \%$ is contributed by other independent variables that are not used in this research. African respondents have adjusted $\mathrm{R}$ square greater than Asian respondents, which is $69.8 \%$ of changes in the dependent variable (busines orientation) is contributed by the independent variables (motivation, family suport and Culture), the remaining 30.2\% were influenced by other factors not examined in this study. Based on this conclusion, H8 was accepted.

\section{Conclusions and Recommendations}

Based on the results of partial test all independent variables have influence on the dependent variable, namely motivation, family suport and culture. All variables motivation, family suport and culture have simultaneously significant influence towards business orientation. According to the descriptive analysis, the average value of Asian respondents is higher than of African respondents, while based on the results of the t-test, F-test, multiple regressions, coefficient correlation and coefficient of determination the results from African respondents were better.

This result is useful for the design of an entrepreneurship curriculum where the culture variable may have big contribution to business orientation. The results of the study can compare with the experience of students with family business in both regions.

Family busines can utilize culture which has the biggest influence to increase respondents' contribution to the development of family business. Respondents who already have education in the business field would rather contribute to raising the family business in more modern ways, such as improving management systems, selling online and providing better facilities for customer satisfaction (Interview, 2019).

For future researchers, in addition to the three independent variables, namely motivation, family support and culture, can add other variables, such as education, self-efficacy, personality, financial support and family relationships with a number of respondents from more diverse and different origins (Europe, Australia and America).

\section{References:}

Adendorff, C. 2011. The Impact of Culture-Related Factors on Good Governance in Greek Family Businesses in South Africa. South African Journal of Business Management. doi:10.4102/sajbm.v42i2.490.

Aldrich, H., Cliff, J. 2003. The pervasive effects of family on entrepreneurship: toward a family embeddedness perspective. Journal of Business Venturing, 573-596.

Armstrong, G., Kotler, P.T. 2005. Marketing: An Introduction, 7th Edition. Pearson.

Bae, T.J., Qian, S. 2014. The Relationship between Entrepreneurship Education and Entrepreneurial Intentions: A Meta-Analytic Review. doi:https://doi.org/10.1111/etap.12095. 
Bandura, A. 1997. Self-efficacy: The exercise of control. W.H. Freeman/Times Books/ Henry Holt \& Co.

Borgia, D. 2005. The Motivation to Become an Entrepreneur. International Journal of Entrepreneurial Behaviour \& Research. doi:10.1108/13552550510580834.

Carbonnier, G., Chakraborty, P., Mulle, E.D. 2010. Asian and African Development Trajectories Revisiting Facts and Figures. Traverse Conference.

Chaudhary, R. 2017. Demographic Factors, Personality and Entrepreneurial Inclination. Education and Training, 59(2), 171-187. doi:https://doi.org/10.1108/ET-02-20160024.

Chu, H.M., Benzing, C., McGee, C. 2007. Ghanaian and Kenyan entrepreneurs: A comparative analysis of their motivations, success characteristics and problems. Journal of Developmental Entrepreneurship, 12, 3, 295-322. doi:10.1142/S108494670700069.

Chrisman, J., Chua, J.H., Steier, L.P. 2003. An Introduction to Theories of Family Business. Journal of Business Venturing 18, 441-448. doi:10.1016/S0883-9026(03)00052-1.

Djajagunawan, P., Genoveva, G. 2018. The Analyzing of Success Factors Women Entrepreneur. ICFBE, International Conferencen on Family Business and Entrepreneurhsip 2 ${ }^{\text {nd }}$, Bali.

Fayolle, A., Gailly, B. 2008. From Craft to Science: Teaching Model adn Learning Processes in Entrepreneurship Education. Journal of European Industrial Training, 32 (4), 569593. doi: 10.1108/03090590810899838

Figueroa-Armijos, M., Jhonson, T.G. 2016. Entrepreneurship policy and economic growth: Solution or delusion? Evidence from a State Innitiative. Small Business Economic, 47(4), 1033-1047. doi:10.1007/s11187-016- 9750-9.

Frimpong, A.O. 2014. Impact of Entrepreneurship Education on Partnership Venture Intentions. Journal of Behavioural Economics, Finance, Entrepreneurship, Accounting and Transport, 63-69. doi:10.12691/jbe-2-3-2.

Galloway, L., Brown, W. 2002. Entrepreneurship education at university: a driver in the creation of high growth firms? MCB UP Ltd, 44(8/9), 398-405. doi:https://doi.org/10.1108/00400910210449231.

GEM. 2018. Retrieved from Gobal Entrepreneurship Index : https://thegedi.org/globalentrepreneurship-and- development-index/.

Genoveva, G. 2018. A Comparison of Baby Boomers and Millennials Generation in Family Business Performance. Advanced Science Letter, 24(10), 7164-7167. doi:https://doi.org/10.1166/asl.2018.12432.

Genoveva, G. 2019. The Influence of Entrepreneurial Culture on Entrepreneurial Intention Among Business Students. Firm Journal of Management Studies, 4(1), 40-56.

Genty, K.I., Idris, K., Kadir, S.A. 2015. Demographic Factors and Entrepreneurial Success: A Conceptual Review. International Journal of Management Science, 6(8), 366-374.

Hamid, N.F. 2013. Family Business Culture, Entrepreneurial Orientation and the New Economic Policy on Family Business Survival: A Study between the Malays and Chinese of Micro and Small-Sized Family Businesses in Malaysia. University of York : Dissertation.

He, N. 2011. Case Study on the Influence of Chinese Traditional Philosophy to the Enterprise Management. Journal of Management and Strategy, 2. doi:10.5430/jms.v2n3p73.

Indarti, N., Rostiani, R. 2008. Intensi Kewirausahaan Mahasiswa Studi Perbandingan Antara Indonesia, Jepang, dan Norwegia. Jurnal Ekonomi dan Bisnis Indonesia, 23(4), 369384.

Jackson, T. 2011. Prosperity Without Growth: Economics for a Finite Planet. London and 
Washington DC. Earthscan.

Jordaan, A. 2014. Entrepreneurial self-efficacy, intrinsic motivation and entrepreneurial intention as antecedents of nascent necessity entrepreneur business start-up behaviour in South Africa: A longitudinal study. University of Adelaide: dissertation.

Joseph, L.L. 2012. The Impact of Family Influence and Involvement on Career Development. Electronic Theses and Dissertations.

Kluckhohn, C. 1951. Values and Value-Orientations in the Theory of Action: An Exploration in Definition and Classification. Toward a General Theory of Action, 388-433.

Korobova, N. 2012. A comparative study of student engagement, satisfaction and academic success among international and American students. Journal of International Students, 5(10), 72-85.

Kuratko. 2005. The emergence of entrepreneurship education: Development, trends, and challenges. Entrepreneurship Theory and Practice.

Kuratko, M.H.F.D., Cornwall, R.J. 2013. Entrepreneurship Programs and the Modern University. Journal Education of Business, 292.

Kuratko, D.F., Hornsby, J., Covin, J.G. 2013. Diagnosing a Firm's Internal Environment for Corporate Entrepreneurship. Business Horizons. doi:10.1016/j.bushor.2013.08.009.

Larson, N. 2010. Market Segmentation: A Framework for the Determining the Right Target Costumer. Aarhus, School of Business.

Macham, A. 2015. Economic Growth and Development in Sub Saharan Africa, Asia, and Latin America: The Impact of Human Capital. Applied Economic Theses, 12.

Maholtra, N.K. 2014. Structural Equation Modeling With Lisrel: An Initial Vision. REMark, Revista Brasileira de Marketing.

Mclelland, D. 1961. The Achiving Society. Princeton, N.J., Van Nostrand. http://dx.doi.org/10.1037/14359-000.

Ministry of Economics of the Republic of Latvia. 2011. Economic Development of Latvia. Riga: Ministry of Economicsof the Republic of Latvia.

Nandamuri, P.P., Gowtami, C. 2013. A Study of the Association between Entrepreneurial Resourcefulness and Family. Journal of Management Research, 1(2), 15-41.

Naude, W. 2013. Entrepreneurship and Economic Development: Theory, Evidence and Policy. University of Maastric, Discussion paper no. 7507.

Ndofirepi, T.M., Rambe, P. 2017. Entrepreneurship Education and Its Impact on the Entrepreneurship Career. Problems and Perspectives in Management, 191-199.

Nemoto, T., Beglar, D. 2014. Developing Likert- Scale Questionnaires. JALT 2013 Conference Proceeding. Tokyo.

Neneh, B.N. 2017. Family Support and Performance of Women- Owned Enterprises: The Mediating Effect of Family-to-Work Enrichment. The Journal of Entrepreneuship, 26(2), 196-219. doi:10.1177/0971355717716762.

Nugraha, and Indra. 2016. Pengaruh Pelatihan dan Motivasi Terhadap Kinerja Guru (Studi Kasus pada SMA X Kota Bandung). http://repository.widyatama.ac.id/xmlui/handle/123456789/7584

Ozdemir, O., Karadeniz, E. 2009. Entrepreneurship in Turkey and Developing Countries: a Comparison of Activities, Characteristics, Motivation and Environment for Entrepreneurship. MIBES Transactions, 3(1), 30-45.

Patricia, and Silangen, C. 2016. The Effect of Entrepreneurship Education on Entrepreneurial Intention in Indonesia. DeReMa Jurnal Manajemen, 11(1).

Potter, R.R., Binn, T., Elliott, J.A., Nel, E, Smith, D.A. 2017. Geographies of Development: An Introduction to Development Studies. 4th edition. London, Routledge. 
Doi:https://doi.org/10.4324/9781315759319.

Praag, C.M., Praag, P.H. 2008. The Economic Benefits and Costs of Entrepreneurship: A

Review of the Research. Foundations and Trends in Entrepreneurship, 4(2), 65-154. doi:http://dx.doi.org/10.1561/ 0300000012.

Procidano, M., Keller, H. 1983. Measures of Perceived Social Support from Friends and from Family: Three Validation Studies. American Journal of Community Psychology, 1-24.

Robbins, S.P., Judge, T.A. 2013. Organizational Behavior Fifteenth Edition. Prentice Hall.

Sajilan, S., Tehseen, S. 2016. A Conceptual Framework of the Impact of Entrepreneurial Competencies on Small and Medium Enterprises Business Performance in the Malaysian Hospitality and Tourism Industry. Review of Integrative Business and Economic Research, 5.

Schwartz, M. 2009. Cognitive Development and Learning: Analyzing the Building of Skills in Classrooms. Mind, Brain, and Education Society.

Sekaran, U., Bougie, R. 2016. Research Method of Business 7th Edition. John Wiley and Sons.

Sekaran, U., Bougie, R. 2017. Metode Peneltian untuk Bisnis Pendekatan Pengembangan-Keahlian. Jakarta: Salemba Empat.

Senjaya, E.R., Genoveva, G. 2019. Study of Entrepreneurial Intention Among Business Students (A Case of President University Business Students). ICFBE

(International Conferencen on Family Business and Entrepreneurhsip) 3rd. Bali, Indonesia.

Sequiera, J.M., Carr, J.C. 2007. Prior Family Business Exposure as Intergenerational Influence and Entrepreneurial Intent: A Theory of Planned Behavior Approach. Journal of Business Research, 1090-1098.

Shane, S., Locke, E.A., Collins, C. 2003. Entrepreneurial Motivation. Human Resource Management Review, 257-279.

Shen, R.T., Osorio, R.A., Settles, R.A. 2017. Does Family Support Matter? The Influence of Support Factors on Entrepreneurial Attitudes and Intentions of College Students. Academy of Entrepreneurship Journal, 23(1).

Tajpour, M., Moaddab, S., Hosseini, E. 2018. Entrepreneurship education and learning environment in institutions. Proceeding of ICE2018. International Conference on Entrepreneurship. Tehran.

Toma, S.G., Grigore, A.M., Marinescu, P. 2014. Economic Development and Entrepreneurship. Procedia Economics and Finance 8, 436-443. doi:10.1016/S2212-5671(14)00111-7.

Vainionkulma, A. 2016. The Impact of Cultural Differences in Business-to-Business (B2b) Integrated Marketing Communication Channels. Aalto University, School of Business.

Vallejo, M.C. 2009. The Effects of Commitment of Non-Family Employees of Family Firms from the Perspective of Stewardship Theory. Journal of Business Ethic, 87(3), 379390.

Ugwuja, O.G. 2010. Influence of Family Background on the Academic Achievement of Senior Secondary School Students in Nssuka Educational Ground. University of Nigeria, Nigeria.

Werther, W., Chandler, D. 2011. Strategic Corporate Social Responsibility: Stakeholders in a Global Environment. Los Angeles, SAGE. 